This new building should enable Toronto to keep pace in the future with the rapidly increasing demands of medical teaching and research.

\section{Lenin Prizes}

The 1966 Lenin Prizes for Science and Technology have now been announced by the Soviet Government. In science, 21 research workers were awarded prizes for work on eight projects. These included the theory of superconductive alloys; theoretical and experimental research into excitons in crystals; research on the origin of peculiarities in surfaces of negative curvature; work on a mathematical theory of the synthesis of control systems; a cycle of works on irregular problems; investigations into elemental-organic compounds; a chromosome theory of heredity and a theory of mutations; and the book, $X$-Ray Diagnosis of Diseases of the Bones and Joints.

The technologists carried the day by sheer weight of numbers. Altogether 103 research people working on ten projects were awarded prizes in technology. These were for developing a new process for manufacturing a large module gear wheel; for developing and introducing automatic die-casting production of machine components; for developing the means for welding train rails in field conditions; for designing and introducing the mass production of a $100,000 \mathrm{~kW}$ steam heating turbine; for research into complex structures with $p-n$ junctions and developing and introducing the mass production of power silicon rectifiers; for discovering oil and gas deposits in South Mangyshlak and prospecting two other deposits; for scientific verification and practical application of block systems for working oil deposits in the Kuibyshev region; for providing the scientific basis and the practical mechanisms for boring in underground conditions; for developing a practical ladle treatment by liquid synthetic slags for the manufacture of high-quality steels; and for introducing new industrial methods in building the Norilsk town and Combine in the permafrost soil and harsh climatic conditions of the Arctic Circle.

\section{U.S. Science Advisory Committee}

The following new members have been appointed for four-year terms to the United States President's Science Advisory Committee: Dr. T. Bennetr, director, Department of Pathology, Johns Hopkins University; Prof. S. Dreli, professor of physies, Stanford University; W. Hewlexs, president, Hewlett-Packard Company; Pkof. C. Slichter, professor of physics, University of Illinois; Dr. C. Townes, provost, Massachusetts Institute of Technology.

\section{University News:}

Massachusetts Institute of Technology

Dr. Herrbert S. BRIDGE has been appointed professor of physics at the Massachusetts Institute of Technology. Dr. Bridge has worked with the Cosmic Ray Group of the M.I.T. Laboratory for Nuclear Seience since 1946 and has been a principal investigator in NASA's solar wind experimonts. Dr. Jerome Y. Lettvin has been appointed professor of communications physiology with faculty association in both the Department of Biology of the School of Science and the Department of Electrical Engineering in the School of Engincoring.

Strathclyde

Dr. Peter J. Heald, head of the Department of Animal Biochemistry at the Twyford Laboratories, Ltd., Park Royal, London, has been appointed to the chair of biochemistry in the University of Strathclyde with effect from September.

Sussex

DR. R. J. TAYLER, at present Fellow of Corpus Christi College, Cambridge, has been appointed professor of astronomy.

\section{Appointments}

Council of the Scottish Marine Biological Association has appointed Mr. R. I. Currie, of the National Institute of Oceanography, to be director of the Millport/Oban Laboratory in succession to Dr. C. H. Mortimer. At the same time Mr. R. S. Glover will become director of the Oceanographic Laboratory, Edinburgh. Mr. Currie and Mr. Glover will act as joint secretaries to the Association.

Admiral of the Fleet the Earl Mountbatten of Burma has been elected a Fellow of the Royal Socjety, under the statute of the Society which provides for the election of persons who have either rendered conspicuous service to the cause of science or are such that their election. would be of signal benefit to the Society.

Prof. E. R. Laithwaite, professor of heevy electrical engineering at the Imperial College of Science and Technology, University of London, has been awarded the S. G. Brown Award and Medal of the Royal Socity for 1966, for his work on the linear induction motor.

\section{Announcements}

A NEW Journal of Computational Physics is to be published in July by Academic Press.

A New journal, Chemistry and Physics of Lipids, is to be published quarterly by the North-Holland Publishing Company. The first issue is scheduled for July/ September 1966.

A symposium on "Polymer Degradation" will be held at the Welsh College of Advanced Technology on July 1. Further information can be obtained from the Organizer of Short Courses, Welsh College of Advanced Technology, Cathays Park, Cardiff.

THE 1966 summer meeting of the British Society for the History of Science will be held at St. Amne's College, Oxford, during July 1-2. Further information can be obtained from M. P. Earles, Chelsea College of Science, Manresa Road, London, S.W.3.

THE seventy-second annual conference of the Museums Association will be hold in Sheffield during July 4-8. Further information can be obtained from the Secretary, the Museums Association, 87 Charlotte Street, London, W.1.

As international conference on "Lens Design with Large Computers" will be held in Rochester, New York, during July 5-8. Further information can be obtained from the Institute of Optics, University of Rochester, Rochester, New York.

THE Water Pollution Research Laboratory, at Flder Way, Stevenage, has published a list of substances for which information on their toxicity and biodegradability is available. This list and any enquiries about the properties of a specific substance may be obtained from the director of the Laboratory.

A residential advanced summer school on "Molecular and Cellular Aspects of Immunobiology", sponsored by McGill University and the National Restarch Council of Canada, will be held near Montreal during July 4-15. Further information can be obtained from Prof. A. Sehon, Department of Chemistry, McGill University, Montreal, Quebec.

A CONFERENCE on "The Economics of Automated Materials 'Testing", arranged by the Institution of Engineering Inspection in collaboration with the Materials and Testing Group of the Institute of Physies and the Physical Society, will be held at the Imperial College of Science and Technology, London, during July 4-6. Further information can be obtained from the Secretarv, Institution of Engineering Inspection, 616 Grand Buildings, Trafalgar Square, London, W.C.2. 